\title{
Thromboxane Receptor Activation Mediates Isoprostane- Induced Increases in Amyloid Pathology in Tg2576 Mice
}

\author{
Diana W. Shineman, ${ }^{1}$ Bin Zhang, ${ }^{1}$ Susan N. Leight, ${ }^{1}$ Domenico Pratico, ${ }^{2}$ and Virginia M.-Y. Lee ${ }^{1}$ \\ ${ }^{1}$ Department of Pathology and Laboratory Medicine, Center for Neurodegenerative Disease Research, University of Pennsylvania School of Medicine, \\ Philadelphia, Pennsylvania 19104, and 2Department of Pharmacology, Temple University School of Medicine, Philadelphia, Pennsylvania 19122
}

\begin{abstract}
Alzheimer's disease (AD) amyloid plaques are composed of amyloid- $\beta(\mathrm{A} \beta)$ peptides produced from proteolytic cleavage of amyloid precursor protein (APP). Isoprostanes, markers of in vivo oxidative stress, are elevated in $\mathrm{AD}$ patients and in the Tg2576 mouse model of $\mathrm{AD}$-like $\mathrm{A} \beta$ brain pathology. To determine whether isoprostanes increase $\mathrm{A} \beta$ production, we delivered isoprostane $\mathrm{iPF}_{2 \alpha}-\mathrm{III}$ into the brains of $\mathrm{Tg} 2576$ mice. Although treated mice showed increased brain $\mathrm{A} \beta$ levels and plaque-like deposits, this was blocked by a thromboxane (TP) receptor antagonist, suggesting that TP receptor activation mediates the effects of $\mathrm{iPF}_{2 \alpha}-\mathrm{III}$ on $\mathrm{A} \beta$. This hypothesis was supported by cell culture studies that showed that TP receptor activation increased $\mathrm{A} \beta$ and secreted APP ectodomains. This increase was a result of increased APP mRNA stability leading to elevated APP mRNA and protein levels. The increased APP provides more substrate for $\alpha$ and $\beta$ secretase proteolytic cleavages, thereby increasing $A \beta$ generation and amyloid plaque deposition. To test the effectiveness of targeting the TP receptor for AD therapy, Tg2576 mice underwent long-term treatment with S18886, an orally available TP receptor antagonist. S18886 treatment reduced amyloid plaques, insoluble A $\beta$, and APP levels, thereby implicating TP receptor signaling as a novel target for AD therapy.
\end{abstract}

Key words: Alzheimer's disease; amyloid- $\beta$; APP; lipid peroxidation; isoprostane; thromboxane receptor

\section{Introduction}

Alzheimer's disease (AD) is pathologically marked by senile plaques, neurofibrillary tangles, inflammation, and oxidative stress, ultimately culminating in neuronal loss. Senile plaques are composed mainly of amyloid- $\beta$ (A $\beta$ ) protein produced from the sequential proteolytic cleavage of amyloid precursor protein (APP). Cleavage of APP by $\alpha$-secretase generates secreted APP $\alpha$ $(\operatorname{sAPP} \alpha)$ ectodomain and C83 C-terminal stub, whereas $\beta$-secretase cleavage of APP generates secreted APP $\beta(\operatorname{sAPP} \beta)$ $\mathrm{N}$-terminal and $\mathrm{C} 99 \mathrm{C}$-terminal fragments. The C99 C-terminal fragment is then cleaved by $\gamma$-secretase, thereby generating $\mathrm{A} \beta$ peptides of varying lengths (Ling et al., 2003; Mattson, 2004; Vetrivel and Thinakaran, 2005; Hardy, 2006). A $\beta 1-40$ is the most commonly generated species, whereas $A \beta 1-42$ is less abundant but considered to be the more amyloidgenic and pathologenic species of A $\beta$. Alterations in APP processing, caused by, for example, the presence of $A P P$ gene mutations, can elevate $\mathrm{A} \beta$

\footnotetext{
Received Feb. 14, 2008; revised March 21, 2008; accepted March 26, 2008.

This work was supported by National Institutes of Health Grant AG11542, the Coins for Alzheimer's Research Trust Fund, Cell and Molecular Biology Training Grant T32-GM07229, and the Marian S. Ware Program for Drug Discovery. We thank Drs. John Trojanowski, Kurt Brunden, and Peter Klein for their advice and helpful suggestions on this manuscript; Drs. Linda Kwong and Matthew Winton for their assistance with experiments; Daniel Martinez, Ingrid Solano, and lan Mills for excellent technical support; and Dr. Garret FitzGerald for reagents. V.M.-Y.L. is the John H. Ware III Professor for Alzheimer's Disease Research.

Correspondence should be addressed to Virginia M.-Y. Lee, Center for Neurodegenerative Disease Research, Department of Pathology and Laboratory Medicine, Maloney Building, 3rd Floor, 3600 Spruce Street, Philadelphia, PA 19104-4283. E-mail: vmylee@mail.med.upenn.edu.

DOI:10.1523/JNEUROSCI.0684-08.2008

Copyright $\odot 2008$ Society for Neuroscience $\quad$ 0270-6474/08/284785-10\$15.00/0
}

levels thereby increasing amyloid deposition and the onset of $\mathrm{AD}$ (Selkoe, 1999; Wilson et al., 1999).

Oxidative stress is an early event in $\mathrm{AD}$ pathogenesis and often manifests itself as lipid peroxidation in the brain (Markesbery, 1997; Giasson et al., 2002). Arachidonic acid, a major component of cell membrane phospholipids, is particularly vulnerable to free radical attack and subsequent peroxidation. This reaction generates various isoprostane isoforms that are considered to be specific and sensitive markers of in vivo lipid peroxidation (Morrow et al., 1990; Greco et al., 2000). They are elevated in conditions associated with oxidative stress, including smoking, diabetes, heart disease, and AD. The isoprostane isoforms, iPF $2 \alpha$-III and iPF $2 \alpha$-VI, are elevated in AD patients (Montine et al., 1998; Pratico et al., 1998; Tuppo et al., 2001) as well as in patients with mild cognitive impairment, a prodromal phase of $\mathrm{AD}$ (Pratico et al., 2002). In addition, the Tg2576 mouse model of $A D$-like $A \beta$ pathology (Hsiao et al., 1996), in which $\mathrm{APP}_{695}$ with the Swedish familial mutation $\left(\mathrm{APP}_{s \mathrm{w}}\right)$ is overexpressed, also shows elevated iPF $2 \alpha$-VI levels before the onset of amyloid plaque formation (Pratico et al., 2001). Because isoprostanes are elevated early in the disease process, they may play a mechanistic role in the onset or progression of $\mathrm{AD}$.

Although isoprostanes are commonly used as markers of oxidative stress, they also exert biological activities. The isoprostane iPF2 $\alpha$-III (IsoP) can induce vasoconstriction and platelet aggregation (Morrow et al., 1992; Audoly et al., 2000), as well as promote atherogenesis (Tang et al., 2005), through activation of the thromboxane receptor, historically named the thromboxaneprostanoid (TP) receptor. The TP receptor is a seven transmembrane G-protein-coupled receptor that is present in many tissues, 
including cardiovascular and brain tissues (Borg et al., 1994; Gao et al., 1997; Kinsella et al., 1997; Huang et al., 2004).

Given that IsoP is elevated in human $\mathrm{AD}$ brains and has been shown to exert biological activity in other systems, we asked whether IsoP plays an active role in $\mathrm{AD}$ pathogenesis in the Tg2576 mouse model. Our in vivo and in vitro studies reported here suggest that IsoP promotes amyloid plaque formation by increasing $A \beta$ levels through TP receptor activation, and that TP receptor inhibition may prove beneficial in the treatment of AD.

\section{Materials and Methods}

Materials. IsoP, 8-iso PGF3 $\alpha$ (F3 $\alpha)$, SQ29,548 (SQ), and $\left[1 S-\left[1 \alpha, 2 \alpha(Z), 3 \beta\left(1 E, 3 S^{*}\right), 4 \alpha\right]\right]-7-$ [3-[3-hydroxy-4-(4-iodophenoxy)-1-butenyl]7 -oxabicyclo[2.2.1]hept -2 -yl] -5 -heptenoic acid (I-BOP) were purchased from Cayman Chemical (Ann Arbor, MI). S18886 was obtained from Institut de Recherches Servier (Suresnes, France). Cyclohexamide was purchased from Sigma-Aldrich (St. Louis, MO), and osmotic pumps were purchased from Alzet (Cupertino, CA). Tg2576 mice (Hsiao et al., 1996) were housed in accordance with University Institutional Animal Care and Use Committee (IACUC) guidelines, and all procedures were approved by the IACUC. Fulllength pCMV-Notch 1 construct was obtained from Dr. Robert Doms (University of Pennsylvania, Philadelphia, PA). TP $\alpha$-pcDNA3.1 construct was obtained from Dr. Garret FitzGerald (University of Pennsylvania, Philadelphia, PA). Other constructs in pcDNA3.1 used here include wild-type APP cDNA (APPwt), APPsw, APP $\triangle K K$ (endoplasmic reticulum targeted APP), and APP-TGN (trans-Golgi network targeted APP), and all have been described previously (Cook et al., 1997; Skovronsky et al., 2000; Wilson et al., 2002). To generate APPwtpZeoSV2 and APPwt-pcDNA5/TO, APPpcDNA3.1, pZeoSV2 $(+)$, and pcDNA5/TO were digested with HindIII and NotI, and APP insert was ligated into either pZeoSV2 $(+)$ or pcDNA5/TO.

Osmotic pump implantation and treatment. Mice were treated with artificial CSF (aCSF) (1.3 $\mathrm{CaCl}_{2}, 1.2 \mathrm{MgSO}_{4}, 3 \mathrm{KCl}, 0.4 \mathrm{KH}_{2} \mathrm{PO}_{4}, 25$ $\mathrm{NaHCO}_{3}$, and $122 \mathrm{NaCl}, \mathrm{pH} 7.35$ ), IsoP at $1 \mu \mathrm{g} / \mathrm{kg}$ body weight, a biologically inactive isoprostane $\mathrm{F} 3 \alpha$ at $1 \mu \mathrm{g} / \mathrm{kg}$ body weight, or with a TP receptor antagonist SQ at $2 \mathrm{mg} / \mathrm{kg}$ (Tang et al., 2005). One cohort was treated with IsoP and SQ together. Compounds were diluted from ethanol stocks into aCSF for infusion. Alzet pumps $(100 \mu \mathrm{l})$ were filled with indicated compounds and kept in $0.9 \%$ saline at $37^{\circ} \mathrm{C}$. Mice were anesthetized by intraperitoneal injection of ketamine hydrochloride $(1 \mathrm{mg} / 10$ g) and xylazine $(0.1 \mathrm{mg} / 10 \mathrm{~g})$. After being shaved on the head and back, a cannula was inserted into the right lateral ventricle using sterotaxic coordinates [frontal pole (F-P), $0.5 \mathrm{~mm}$; mediolateral (M-L), $1.0 \mathrm{~mm}$; dorsoventral (D-V), 2.7-3 mm]. Instant dental cement was used to secure the cannula to the skull, and an osmotic pump was placed subcutaneously on the back. After surgery, mice were housed individually. After 3 weeks of infusion, the pump was replaced with a fresh $100 \mu$ l pump filled with the indicated compound, and mice were infused for another 3 weeks before being killed.

Intrahippocampal microinjections. Mice were anesthetized and prepared as described above. A volume of $5 \mu$ l of either I-BOP ( $5 \mu \mathrm{M}$ in $2.5 \%$ $\mathrm{EtOH}$ in saline) or control (2.5\% $\mathrm{EtOH}$ in saline) were drawn into a
Hamilton microinjection syringe and injected into the hippocampus, using stereotaxic coordinates (F-P, $3.1 \mathrm{~mm}$; M-L, $2.4 \mathrm{~mm}$; D-V, 3.7-4 $\mathrm{mm} ; 12^{\circ}$ angle to vertical level), and the syringe was removed $10 \mathrm{~min}$ postinjection. Mice were killed $20 \mathrm{~h}$ after injection.

S18886 treatment. Seven-month-old female Tg2576 mice were treated with $5 \mathrm{mg} / \mathrm{kg} / \mathrm{d}$ of S18886 dissolved in drinking water. Calculations were based on the assumption that a mouse drinks an average of $5 \mathrm{ml}$ of water per day. Water was changed weekly for a total of 6 months. After treatment, mice were anesthetized and perfused with PBS as described below. One hemisphere of each brain was fixed in $4 \%$ neutral-buffered formalin (NBF) for $24 \mathrm{~h}$, whereas the other hemisphere was dissected into cortex and hippocampus regions and frozen on dry ice for biochemical analysis.

Immunohistochemistry. Mice were perfused intracardially with PBS plus heparin after being lethally anesthetized by an intraperitoneal injection of ketamine hydrochloride $(1 \mathrm{mg} / 10 \mathrm{~g})$ and xylazine $(0.1 \mathrm{mg} / 10 \mathrm{~g})$, in accordance with protocols approved by the University of Pennsylvania. The left hemisphere was fixed in $4 \%$ NBF for $24 \mathrm{~h}$, whereas cortex and hippocampus from the right hemisphere were dissected and frozen on dry ice for biochemical analysis. NBF-fixed brain hemispheres were dehydrated and embedded in paraffin blocks as described previously (Trojanowski et al., 1989). Tissue sections $(6 \mu \mathrm{m})$ were cut and mounted onto 3-aminopropyltriethoxysilane-coated slides. Nonserial sections were stained for amyloid plaques using 4G8, an anti-A $\beta$ antibody, with standard avidin-biotin-peroxidase methods with diaminobenzidine as 
A
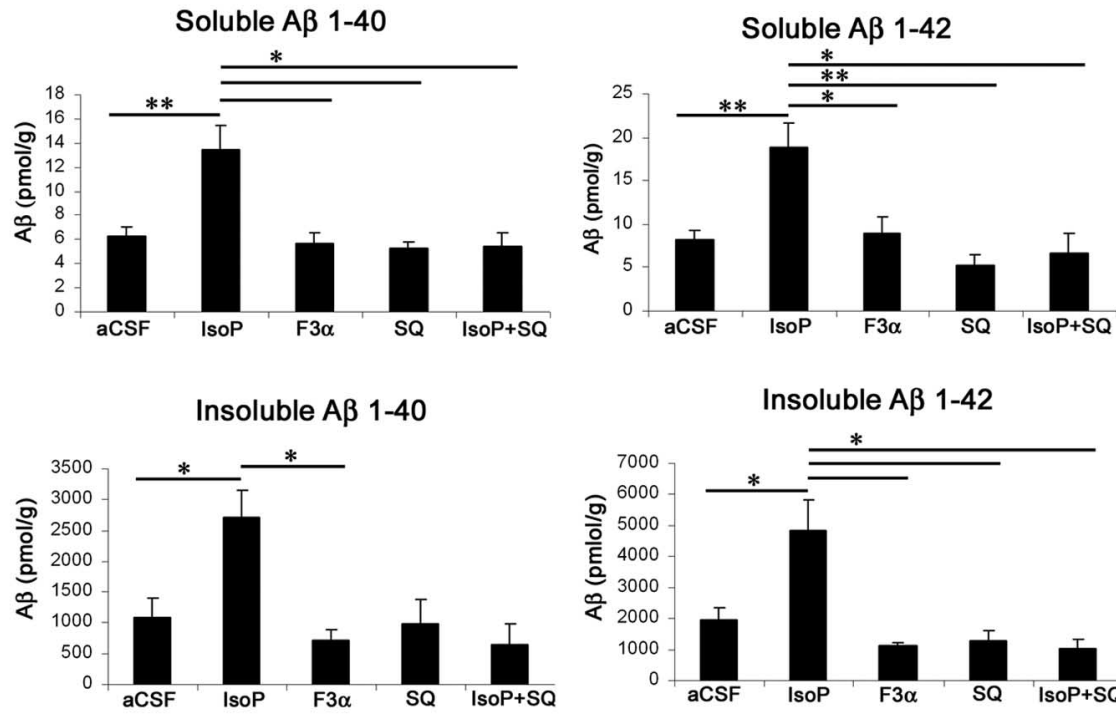

B

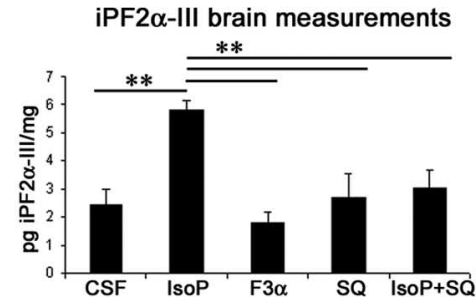

Figure 2. IsoP increases soluble and insoluble $A \beta 1-40$ and $A \beta 1-42$ levels in a thromboxane receptor-dependent manner. $A$, Sandwich ELISA of soluble (high-salt extracted) and insoluble (70\% formic acid extracted) $A \beta$ from hippocampus brain homogenates. Mice treated with IsoP show an increase in $A \beta$ levels compared with CSF-treated mice. This increase is blocked by addition of $S Q$. $B$, Endogenous iPF $2 \alpha$-III levels from high-salt hippocampus brain homogenates from treated mice. Numbers of mice treated per group: $\mathrm{CSF}, n=8 ;$ I IsOP, $n=9 ; \mathrm{F} 3 \alpha, n=4 ; \mathrm{SQ}, n=4 ; \mathrm{ISOP}+\mathrm{SQ}, n=3$. Data are expressed as mean $\pm \mathrm{SEM}$. ${ }^{*} p<0.05,{ }^{* *} p<0.01$.

chromogen. For quantification of amyloid plaque burden, images of stained sections from the sensory cortex and hippocampus were analyzed using Image-Pro Plus software to determine percentage of area occupied by amyloid plaques. Analysis was performed in a coded manner.

Brain extractions and sandwich ELISA. Dissected cortex and hippocampus were homogenized separately and sonicated in either $4 \mathrm{ml}$ of high-salt buffer (50 mm Tris base, pH 7.6, 10 mм EGTA, 5 mм $\mathrm{MgSO}_{4}$ $0.75 \mathrm{M} \mathrm{NaCl}, 0.02 \mathrm{M} \mathrm{NaF}$ ) for every $150 \mathrm{mg}$ of tissue or $1 \mathrm{ml}$ of radioimmunoprecipitation assay (RIPA) buffer $(0.5 \%$ sodium deoxycholate, $0.1 \%$ SDS, $1 \%$ NP-40, 5 mm EDTA, $\mathrm{pH} 8.0,1 \mu \mathrm{g} / \mathrm{ml}$ protease inhibitor mixture and $0.5 \mathrm{~mm}$ PMSF) for every $150 \mathrm{mg}$ of tissue. Samples were centrifuged at $100,000 \times g$ for $30 \mathrm{~min}$ at $4^{\circ} \mathrm{C}$, and supernatant was collected. Pellets from high-salt extraction were sonicated in RIPA buffer as described above. Pellets following RIPA extraction were sonicated in $70 \%$ formic acid (FA) at $2 \mu \mathrm{l} / \mathrm{mg}$ tissue, and centrifuged at $100,000 \times g$ for $30 \mathrm{~min}$ at room temperature (RT). FA samples were diluted 20-fold in $1 \mathrm{~m}$ Tris base buffer. Sandwich ELISA was performed as described previously (Gravina et al., 1995). Briefly, highsalt or RIPA soluble fractions were diluted onto plates coated with Ban50 as the capture antibody. After incubation overnight at $4^{\circ} \mathrm{C}$, plates were washed and incubated with HRP-conjugated BA27 (A $\beta 40$ specific) or BC05 (A $\beta 42$ specific) antibodies for $4 \mathrm{~h}$ at room temperature followed by chemiluminescence detection. Values were calculated by comparison with standard curves of $A \beta 40$ and $A \beta 42$ synthetic peptides (Bachem, Torrance, CA).

IPF2 $\alpha$-III measurements. Measurements were performed as described previously (Pratico et al., 1998). Briefly, high-salt extracted brain frac- tions and fractions that were spiked with a standard amount of iPF $2 \alpha$-III underwent standard lipid extraction. The extracts were then purified by thin-layer chromatography and finally analyzed by gas chromatography/mass spectrometry. For iPF $2 \alpha$-III biodistribution and clearance experiments, wild-type mice were injected in the lateral ventricle with $9 \mu \mathrm{Ci}$ of $\mathrm{H}^{3}$-8-isoprostaglandin F2 $\alpha$ (Cayman Chemical) evaporated under nitrogen gas and resuspended in PBS. Mice were killed at 2 or $24 \mathrm{~h}$ after injection, and indicated brain regions were dissected and monitored for radioactivity.

Cell culture experiments. QBI293 cells [a subclone derived from human embryonic kidney 293 (HEK293) cells], HEK293-APP stably transfected cells, and COS-1 cells were grown in DMEM $4.5 \mathrm{~g} / \mathrm{L}$ glucose (Invitrogen, Carlsbad, CA), $10 \%$ fetal bovine serum, L-glutamine, and penicillin/streptomycin at $37^{\circ} \mathrm{C}$ and $5 \% \mathrm{CO}_{2}$ according to standard protocols. Cells were transfected at $90 \%$ confluence with lipofectamine 2000 (Invitrogen) following the manufacture protocol. Where indicated, cells were treated with $50 \mathrm{~nm}$ I-BOP, $10 \mu \mathrm{M}$ IsoP, $1 \mu \mathrm{M}$ SQ, $1 \mu \mathrm{M}$ S18886, $50 \mu \mathrm{g} / \mathrm{ml}$ cyclohexamide, $50 \mu \mathrm{M}$ chloroquine, or $50 \mathrm{mM} \mathrm{NH}_{4} \mathrm{Cl}$. Primary hippocampal neuronal cultures were prepared from mouse embryonic day 17 (E17) C57Bl/6 mice, as described previously (Banker, 1998). Briefly, dissociated cells were plated at a density of $300,000-500,000$ cells/well in poly-lysinecoated 12-well dishes and were maintained in Neural basal media supplemented with B27 (Invitrogen) for 5-7 d before treatment with IsoP or I-BOP as described above. T-Rex-293 cells stably expressing the tet repressor were purchased from Invitrogen. For RNA stability experiments, cells were transfected with APPwtpcDNA5/TO and TP $\alpha$ and treated overnight with $1 \mu \mathrm{g} / \mathrm{ml}$ tetracycline (Sigma-Aldrich) to induce expression. After induction, cells were washed four times with tetracycline-free media over $1 \mathrm{~h}$ and then stimulated with control or I-BOP as described above. $A P P$ mRNA was harvested at the indicated time points.

Western blot analysis. Cells were washed with PBS and lysed in RIPA buffer followed by brief sonication and centrifugation. Protein amount was determined by BCA assay. Equal amounts of protein were loaded and run on a $7.5 \%$ SDS-PAGE tris-glycine gel, transferred to nitrocellulose membrane, and probed with indicated antibodies. Immunoreactive bands were identified either by enhanced chemiluminescence or by $\left[{ }^{125} \mathrm{I}\right]$ labeled goat anti-mouse secondary antibodies when careful quantification was required. For detection of full-length APP, we used a rabbit polyclonal antibody raised to the C terminus of APP (5685) (Lee et al., 2005). For detection of Notch 1, we used a goat polyclonal Notch1 antibody (Santa Cruz Biochemicals, Santa Cruz, CA). For tau protein, we used a rabbit polyclonal antibody raised to recombinant tau (17025) (Ishihara et al., 1999). To detect HA-tagged Akt, we used anti-HA antibody, 12CA5 (Roche Applied Science, Indianapolis, IN). To verify consistent loading, the bottom half of the blot was probed with an anti- $\alpha$ tubulin antibody (Sigma-Aldrich). For detection of secreted sAPP $\alpha$ and $\operatorname{SAPP} \beta$, conditioned media were collected and supplemented with PMSF and protease inhibitors and was either immunoprecipitated with a goat anti-APP antibody (Karen) (Turner et al., 1996) and protein $\mathrm{A} / \mathrm{G}$ beads overnight at $4^{\circ} \mathrm{C}$ or run directly on $7.5 \%$ SDSPAGE. For secreted sAPP $\beta_{\text {sw }}$ measurements, immunoprecipitates were run on $7.5 \%$ SDS-PAGE gel and immunoblotted with an antibody specific to the C terminus of sAPP $\beta_{\mathrm{sw}}$ (\#54) (Lee et al., 2005), 

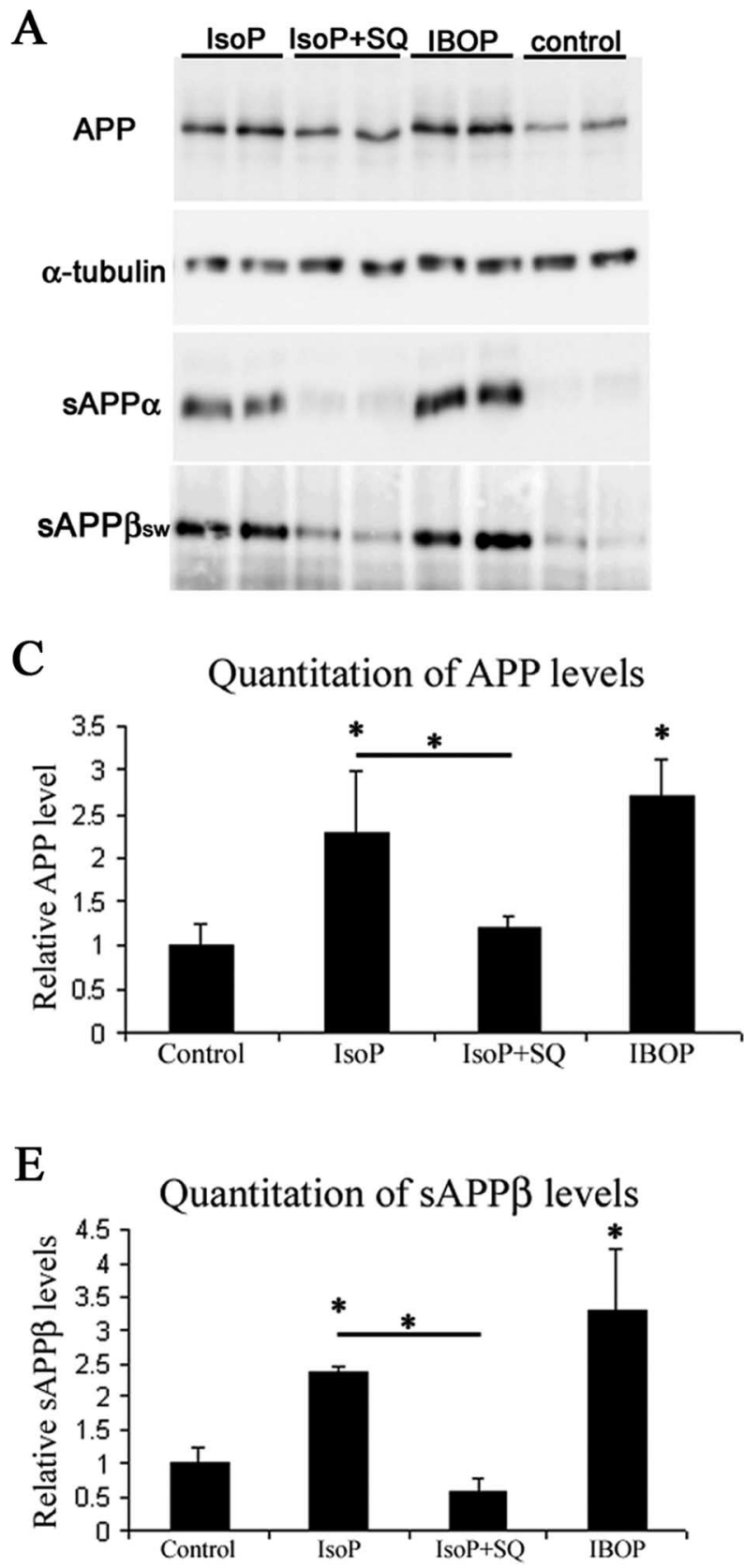

B

\section{Secreted $A \beta$ levels}

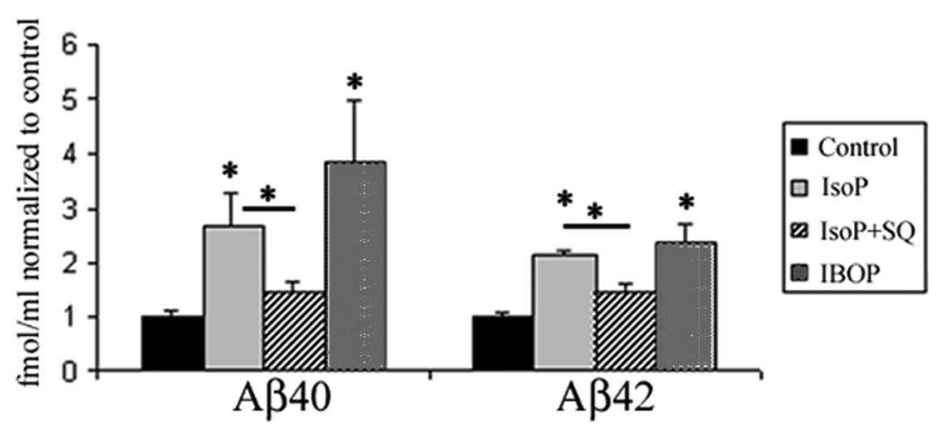

D Quantitation of sAPP $\alpha$ levels

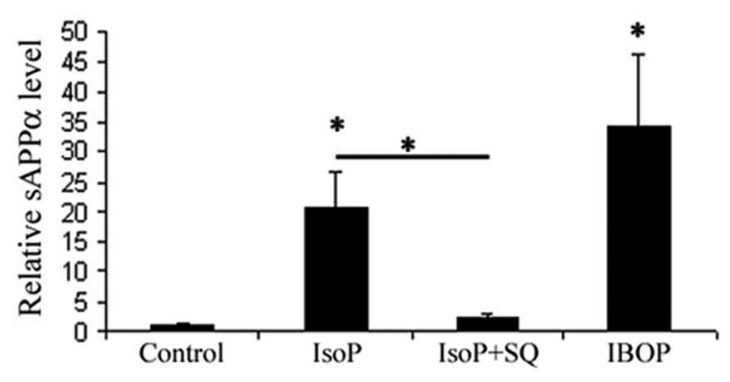

$\mathrm{F}$
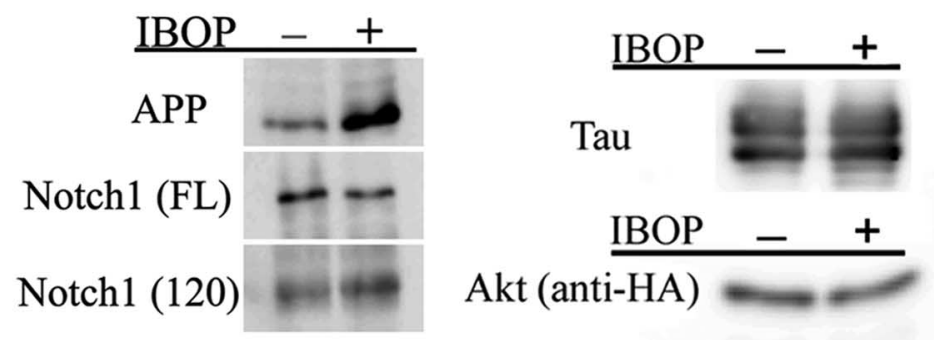

Figure 3. TP receptor activation increases steady-state APP, secreted A $\beta$, and secreted APP ectodomains. QBI293 cells transfected with APP ${ }_{\text {sw }}$ and TP $\alpha$ were treated with indicated compounds for $24 \mathrm{~h} . A$, Treatment with IsoP or TP $\alpha$ agonist, I-BOP, increases APP levels as determined by Western blot analysis of cell lysates. Western blot analysis of cell media shows an increase in both sAPP $\alpha$ and $S A P P \beta_{s w}$.TP receptor antagonist, SQ, blocks the increase in APP, SAPP $\alpha$, and SAPP $\beta_{\text {sw. }} \alpha$-Tubulin Western blot is shown as a loading control. $B$, Secreted A $\beta 40$ and A $\beta 42$ levels are elevated with IsOP and I-BOP treatment as determined by sandwich ELISA of cell media. This elevation is blocked by SQ. Quantification from Western blots of $\operatorname{APP}(\boldsymbol{C}), \operatorname{sAPP} \alpha(\boldsymbol{D})$, and $\mathrm{SAPP} \beta_{\mathrm{sw}}(\boldsymbol{E})$ levels is shown. Data used for quantification are from three independent experiments and are expressed as mean \pm SD. The asterisk indicates differences are statistically significant with $p<0.01$. $\boldsymbol{F}$, Notch1FL, tau, and Akt expressed under control of the cytomegalovirus promoter were transfected into QBI293 cells with the TP receptor. TP receptor activation does not increase Notch1FL, the 120 kDa cleaved fragment of Notch1 (Notch 120), tau, or Akt as assessed by Western blot.

whereas for $\operatorname{sAPP} \alpha$ measurements, media run directly on the gel was probed with Ban50 antibody.

RNA extraction and Northern blot analysis. RNA was extracted from cells using Trizol (Invitrogen) per the manufacture instructions. Between 4 and $6 \mu \mathrm{g}$ of RNA were run on a $1 \%$ agarose denaturing formaldehyde gel and transferred to nylon membrane by capillary action. Membrane was UV-crosslinked and probed overnight at $42^{\circ} \mathrm{C}$ with an APP cDNA probe. APP cDNA probe was generated by gel extraction of EcoRI digested APP-PCDNA3.1 and labeled by random priming using $\left[{ }^{32} \mathrm{P}\right] \alpha$ dCTP. After probe hybridization, blots were washed two times for $5 \mathrm{~min}$ with $2 \times$ SSC, $0.1 \%$ SDS at RT, $0.2 \times$ SSC, $0.1 \%$ SDS one time for $5 \mathrm{~min}$ at
RT, and then one time for $15 \mathrm{~min}$ at $42^{\circ} \mathrm{C}$. Blots were rinsed with $2 \times$ SSC and exposed to phosphoimager plate overnight. After hybridization with APP cDNA probe, blots were stripped with $1 \%$ SDS at $80^{\circ} \mathrm{C}$ two times for 15 min and probed with an actin cDNA probe (Clontech, Mountain View, CA) using the same protocol described above.

Statistical analysis. Data are expressed as mean \pm SEM or \pm SD as indicated in the figures. Results were statistically analyzed using GraphPad Prism 4.0 software (GraphPad Software, San Diego, CA) using ANOVA followed by Bonferroni's posttest or Student's unpaired $t$ test where appropriate. In addition, linear regression was performed where appropriate. Statistical significance was set to a minimum of $p<0.05$. 
A

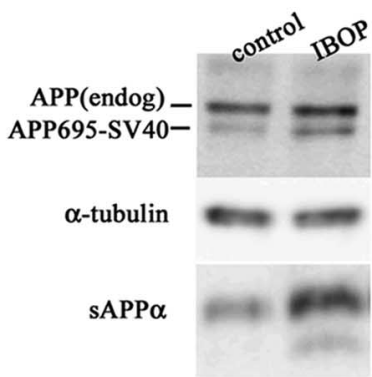

C

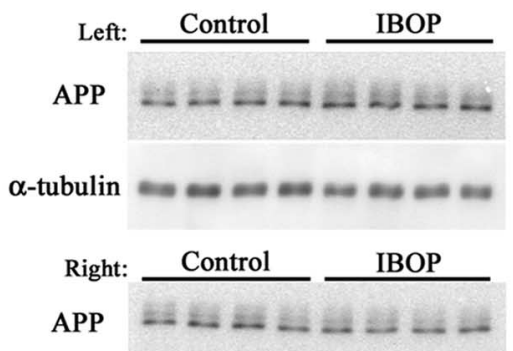

B

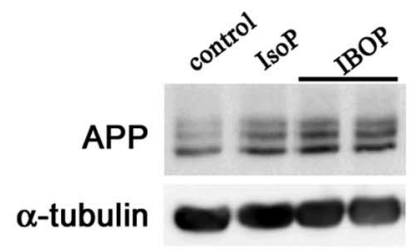

D

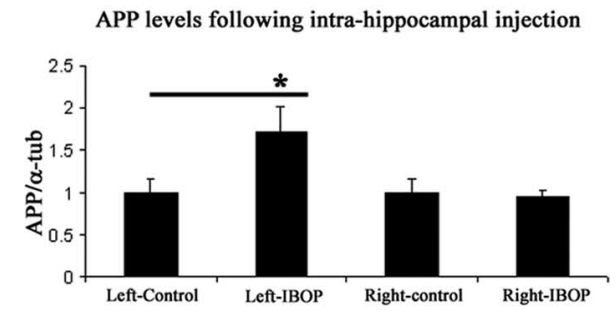

radioactivity in different brain regions $2 \mathrm{~h}$ after injection. We found that the levels of the compound were highest in the hippocampus (supplemental Fig. 1, available at www.jneurosci.org as supplemental material). Consistent with these results, we saw significant increases in both soluble and insoluble $A \beta 1-40$ and $A \beta 1-42$ in this brain region after IsoP treatment (Fig. $2 A$ ). These increases in $\mathrm{A} \beta$ were significantly blocked by $\mathrm{SQ}$, and nonbiologically active F3 $\alpha$ did not produce any changes in $\mathrm{A} \beta$ levels compared with aCSF (Fig. 2A).

Mice treated with IsoP also showed elevated endogenous IsoP in hippocampal homogenates 1 week after the completion of treatment (Fig. $2 \mathrm{~B}$ ), reflecting the effects of elevated amyloid in these treated mice. This increase is not attributable to residual levels of exogenous IsoP from the treatment, because pharmacokinetic studies using $\mathrm{H}^{3}$-iPF2 $\alpha$-III suggest complete elimination of this compound by $24 \mathrm{~h}$ (supplemental Fig. 1, available at www. jneurosci.org as supplemental material). Moreover, there was no elevation of iPF $2 \alpha$-III levels in the IsoP+SQ treated group, further ruling out the possibility that the IsoP measured is from the treatment itself. These data support a feedforward model where an early event before the onset of plaque deposition causes ox-

\section{Results}

IsoP increases amyloid plaque formation and $\mathrm{A} \beta$ levels in a TP receptor-dependent manner

To determine whether IsoP might play a causative role in promoting $\mathrm{AD}$ pathogenesis, 10 -month-old Tg2576 mice were continuously infused with IsoP or aCSF for 6 weeks. After treatment, mice were killed, and one hemisphere of the brain was fixed for immunohistochemistry analysis, whereas the other hemisphere was used for biochemical experiments. Mice treated with IsoP exhibited significantly increased amyloid plaques in the sensory cortex compared with CSF-treated mice (Fig. 1). This area of the cortex was analyzed because of its relative proximity to the IsoP injection site. There was a trend toward an increased plaque burden with IsoP treatment in the hippocampus $(p=0.09)$. Because IsoP is known to exert biological effects through activation of the $\mathrm{TP}$ receptor, we asked whether TP receptor inhibition could block the increase in amyloid plaques seen with IsoP treatment. Mice were treated with TP receptor antagonist SQ alone, IsoP+SQ together, or with $\mathrm{F} 3 \alpha$, a biologically inactive isoprostane that does not activate the TP receptor. In the IsoP+SQ treatment group, SQ significantly blocked the increase in amyloid plaques induced by IsoP in the cortex (Fig. 1). F3 $\alpha$ did not produce any significant changes in amyloid plaques compared with control CSF (Fig. 1), further supporting TP receptor activation as the mechanism for increased amyloid plaque formation.

For biochemical analysis, we focused on the hippocampus region. Unlike the cortex, which when extracted for biochemical analysis contains areas both proximal and distal to the site of infusion, the hippocampus is likely to get a higher and more constant exposure to the compound. To validate this hypothesis, we injected $\mathrm{H}^{3}$-iPF $2 \alpha$-III into the lateral ventricle and monitored

idative stress and increases IsoP production, which in turn promotes amyloid pathology that leads to further increases in oxidative stress and IsoP generation.

\section{TP receptor activation increases steady-state APP and APP cleavage products}

To determine a mechanism of how TP receptor activation could increase $A \beta$ production and promote amyloid plaque formation, we cotransfected $\mathrm{TP}$ receptor and $\mathrm{APP}_{\mathrm{sw}} \mathrm{cDNAs}$ into QBI293 cells and stimulated the cells with IsoP or I-BOP, a potent TP receptor agonist. IsoP and I-BOP treatment significantly increased the levels of steady-state $\mathrm{APP}_{\mathrm{sw}}, \mathrm{sAPP} \beta_{\mathrm{sw}}$, $\mathrm{A} \beta 1-40$, and $\mathrm{A} \beta 1-42$ by twofold to threefold (Fig. $3 A-C, E$ ). Levels of sAPP $\alpha$ were increased $>20$-fold (Fig. $3 A, D$ ). SQ significantly blocked the increase in APP and APP cleavage products seen with IsoP treatment (Fig. $3 A-E$ ), further supporting the hypothesis that IsoP functions via TP receptor activation in this paradigm. Similar results were observed when QBI293 cells were transiently transfected with TP receptor and $\mathrm{APP}_{\mathrm{wt}}$. Also, treatment with SQ alone did not produce any significant effects (data not shown). Therefore, IsoP treatment appears to increase APP levels, thereby providing more substrate for $\alpha$ and $\beta$ secretase cleavages, resulting in an increase in $A \beta$ levels that augments $A \beta$ plaque pathology. To test the specificity of this effect for APP, we coexpressed full-length Notch1 (Notch1FL), tau, and Akt cDNAs with TP receptor. Stimulation with I-BOP did not increase Notch1FL, Notch1 $120 \mathrm{kDa}$ cleavage product (Notch 120), tau, or Akt protein levels, suggesting the effects of TP receptor activation on APP are quite specific. Furthermore, the I-BOP-stimulated increase in APP levels and sAPP $\alpha$ secretion is independent of the 
promoter used in our transfection experiments, because both endogenous APP and APP expressed under control of the SV40 promoter (Fig. 4A) showed similar increases in QBI293 cells. These data demonstrate that the effect of TP receptor activation on APP levels most likely occurs posttranscriptionally.

\section{TP receptor activation increases both} endogenous and neuronal APP levels

To provide evidence that the mechanism we observe also applies to primary neuronal cells, we treated dissociated wildtype mouse primary hippocampal neurons with either IsoP or I-BOP and measured APP protein levels by Western blot (Fig. $4 B$ ). In response to these agonists, endogenous mouse APP levels were significantly increased with both IsoP and I-BOP treatment. In addition, an increase in endogenous APP was also observed after I-BOP stimulation in COS-1 cells (data not shown), which express endogenous levels of the TP receptor (Hirata et al., 1991). Finally, we injected I-BOP or vehicle into the left hemisphere hippocampus of 5-month-old Tg2576 male mice. APP levels in hippocampal homogenates obtained $24 \mathrm{~h}$ postinjection were assessed by $\left[{ }^{125} \mathrm{I}\right]$ labeled secondary antibodies for quantitative Western blot (Fig. 4C,D) and were moderately, but significantly, elevated in the injected but not in the uninjected side of the hippocampus.

\section{TP receptor activation elevates APP levels through increased mRNA stability}

To provide further insights into how TP receptor activation increases APP levels, we tested whether TP receptor activation stabilized APP by altering APP protein degradation. We measured APP protein stability in HEK293-APP stable cells transfected with vector or TP receptor. To measure APP degradation rates, cells were stimulated overnight with either control (vehicle) or I-BOP and then were treated with cycloheximide to block protein synthesis. APP protein levels were monitored over the indicated time points. Although there was an increase in APP levels at the initial time point with TP receptor overexpression and a further increase with additional I-BOP activation, there was no significant change in APP protein stability over the times tested (Fig. $5 A, B)$. In addition, I-BOP stimulation increased APP levels even when APP constructs were used that resulted in retention of the protein in the ER or Golgi (supplemental Fig. $2 \mathrm{~A}$, available at www.jneurosci.org as supplemental material), indicating that TP receptor activation increases APP levels early in APP maturation. This increase in APP was also not attributable to reduced lysosomal degradation, because I-BOP was still able to increase APP levels under conditions of inhibition of lysosomal degradation (supplemental Fig. 2 B, available at www.jneurosci.org as supple-

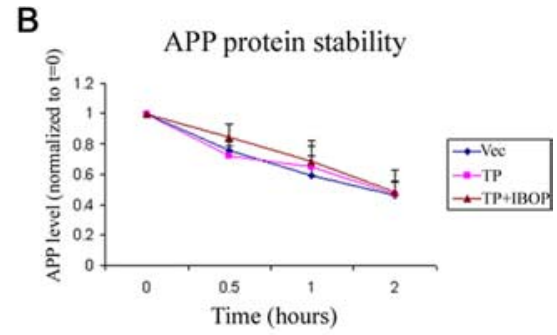

D

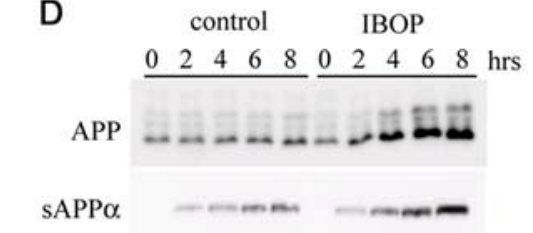

$\alpha$-tubulin $\ldots \ldots \ldots \ldots \ldots \ldots$

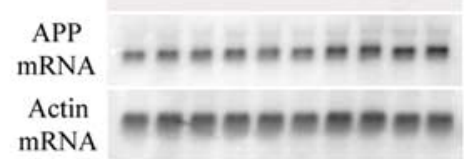

G

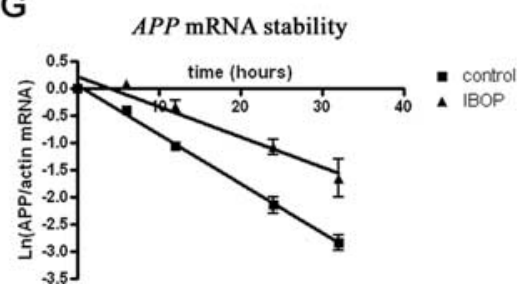

Figure 5. TP receptor activation elevates APP levels through increased mRNA stability. $\boldsymbol{A}$, After overnight treatment with I-BOP where indicated, cells were treated with cycloheximide and harvested at the indicated time points to measure APP protein the presence or absence of I-BOP stimulation. APP mRNA levels are elevated with I-BOP stimulation. Actin mRNA is shown as an either control (vehicle) or I-BOP treatment. Error bars represent SEM. $\boldsymbol{F}$, Northern blot of APP mRNA from T-Rex-293 cells

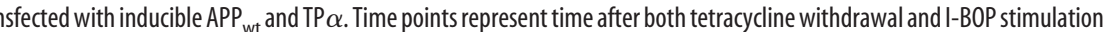
Actin mRNA is shown as an internal control. G, Quantitation of three independent RNA stability experiments. Control $t^{1 / 2}, 6.1 \mathrm{~h}$; $\mathrm{I-BOP} t^{1 / 2}, 13.1 \mathrm{~h}$. The slopes of the lines are significantly different $(p<0.0001)$. Error bars represent SD.

mental material). Therefore, TP receptor activation does not appear to affect APP at the posttranslational level.

Because elevated APP protein levels after I-BOP treatment cannot be explained by altered APP protein degradation, we examined APP mRNA levels after TP receptor activation. In stably transfected HEK-APP cells, TP receptor activation increases APP mRNA (Fig. 5C). Through careful time course studies, it appears that APP mRNA is elevated in parallel with APP protein levels (Fig. $5 D, E$ ). sAPP $\alpha$ is also elevated over the $8 \mathrm{~h}$ time course with I-BOP stimulation and accumulates in the media (Fig. 5D). Because of these parallel changes in both mRNA and protein and because of the promoter independence, we hypothesized that the increase in APP seen with TP receptor activation occurs posttranscriptionally, presumably through increased APP mRNA stability. To directly measure changes in APP mRNA stability with TP receptor activation, a tetracycline-inducible $\mathrm{APP}_{\mathrm{wt}}$ construct was cotransfected with TP $\alpha$ into T-Rex-293 cells. APP expression was 
A

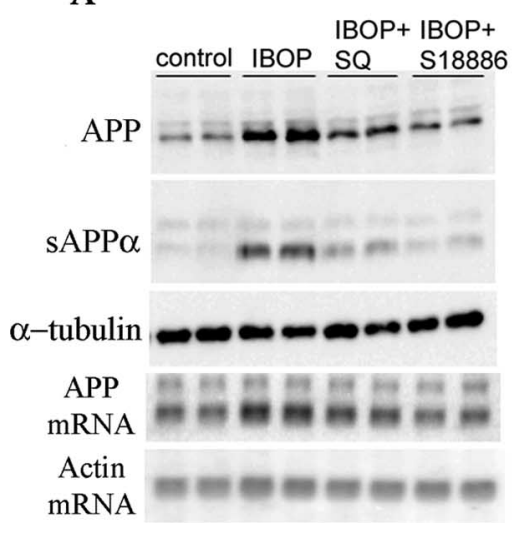

B

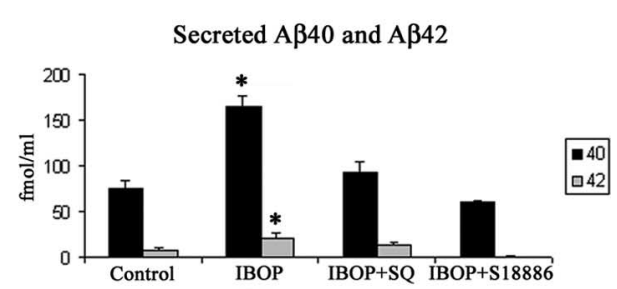

Figure 6. TP receptor antagonist $\mathrm{S} 18886$ blocks increases in APP protein and APP mRNA. A, QBI293 cells were transfected with APP and TP receptor and stimulated with I-BOP in the presence or absence of TP receptor antagonists SQ or S18886. Both SQ and S18886 block the I-BOP-induced increase in APP and SAPP $\alpha$ as shown by Western blot analysis of cell lysate and media. $\alpha$-Tubulin Western blot is shown as a loading control. SQ and S18886 are also able to block the I-BOP-induced increase in APP mRNA as assessed by Northern blot analysis. Actin mRNA is shown as a loading control. $\boldsymbol{B}, \mathrm{SQ}$ and $\mathrm{S} 18886$ are also able to block I-BOPinduced increase in secreted $A \beta 40$ and $A \beta 42$ as determined by sandwich ELISA measurements. Data are expressed as mean \pm SD. ${ }^{*} p<0.05$.

A

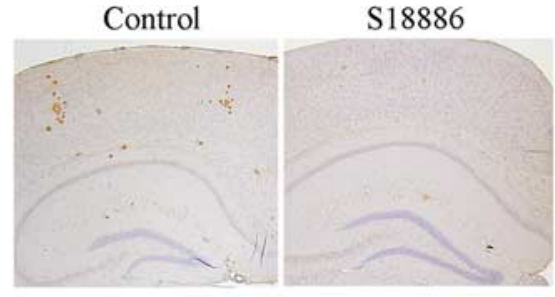

$\mathrm{C}$

Insoluble $A \beta$ 1-40

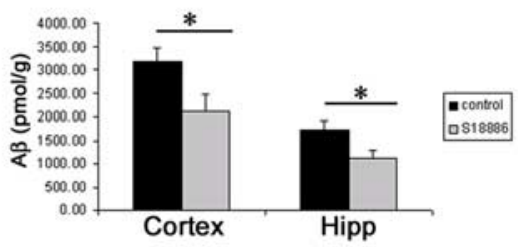

$\mathrm{E}$

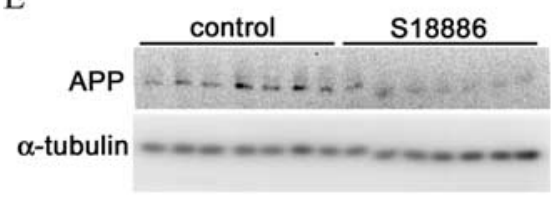

B

Amyloid Plaque Quantitation

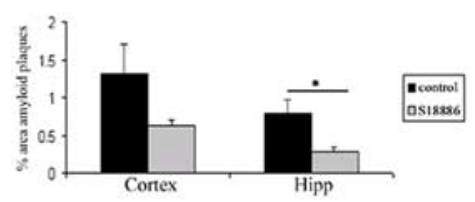

$\mathrm{D}$

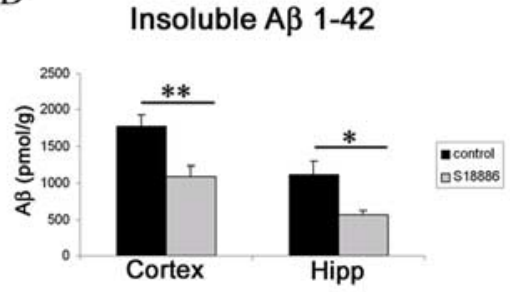

F APP levels following $\mathbf{S} 18886$ treatment

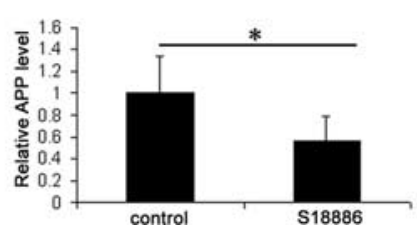

Figure 7. Treatment with orally active TP receptor antagonist $\$ 18886$ reduces amyloid plaques and A $\beta$ levels. Seven-monthold Tg2576 mice were treated for 6 months with $5 \mathrm{mg} / \mathrm{kg} / \mathrm{d}$ of $\$ 18886$ compound via drinking water. A, Immunohistochemistry of amyloid plaques using anti-A $\beta$ (4G8) antibody. Magnification, $4 \times$. Scale bar, $500 \mu \mathrm{m}$. Data are quantified in $B$ as percentage of area occupied by amyloid plaques. Sandwich ELISA of insoluble (70\% formic acid extracted) $A \beta 40(C)$ and $A \beta 42(D)$ from cortex and hippocampus brain homogenates is shown. Data are expressed as mean \pm SEM. ${ }^{*} p<0.05$, ${ }^{* *} p<0.01$. E, Quantitative Western blots using [ ${ }^{125}$ ]l-labeled goat anti-mouse secondary antibodies of mouse hippocampus brain lysates from S18886-treated mice. Levels of APP and $\alpha$-tubulin loading control are shown. $F$, Quantitation of [ ${ }^{125}$ I]-labeled Western blots. Data are expressed as mean $\pm S D$. ${ }^{*} p<0.05,{ }^{* *} p<0.01$.

induced with tetracycline, and APP mRNA was monitored at time points after tetracycline withdrawal in the presence or absence of I-BOP stimulation. I-BOP stimulation significantly increased APP mRNA stability and increased APP mRNA half life from 6.1 to $13.1 \mathrm{~h}$ (Fig. $5 F, G$ ).

Treatment with S18886, an orally active $\mathrm{TP}$ receptor antagonist, reduced amyloid plaques and insoluble $A \boldsymbol{\beta}$

Because we observed increased amyloid pathology after TP receptor activation in vivo, we wanted to test whether long-term $\mathrm{TP}$ receptor inhibition in an established mouse model of AD-like pathology would prevent activation of the receptor by endogenous IsoP, resulting in decreased amyloid plaques and $A \beta$ levels. For these studies, we used an orally active TP receptor antagonist (S18886) that, like SQ, is able to block I-BOP-induced increases in APP protein, APP mRNA, sAPP $\alpha$, and secreted $A \beta$ in QBI293 cells expressing both APP and TP receptor (Fig. 6A,B). Sevenmonth-old $\mathrm{Tg} 2576$ mice were treated with S18886 for 6 months and, compared with controls, S18886 treatment significantly decreased amyloid plaques in the hippocampus and caused a trend toward a decrease of amyloid plaques in the cortex (Fig. $7 A, B$ ). Although there was no significant changes in soluble $A \beta$ (data not shown), insoluble $A \beta 40$ and $A \beta 42$ levels were significantly reduced after S18886 treatment (Fig. 7C,D). In addition, mice treated with S18886 also exhibited a significant decrease in APP protein levels (Fig. $7 E, F)$ as assessed by quantitative [ $\left.{ }^{125} \mathrm{I}\right]$ Western blot. These data demonstrate that S18886 and other TP receptor antagonists may prove beneficial in preventing amyloid plaque formation, one of the major hallmarks of $\mathrm{AD}$.

\section{Discussion}

Numerous studies have demonstrated that isoprostanes are biomarkers for $\mathrm{AD}$ and mild cognitive impairment (Grossman et al., 2005; Montine et al., 2005; de Leon et al., 2006), and that this elevation appears to be somewhat specific for $\mathrm{AD}$ compared with other neurodegenerative diseases like Parkinson's disease (Pratico et al., 1998) and frontotemporal dementia (Yao et al., 2003). It is still unknown, however, if isoprostanes play an active role in promoting the disease process. In this study, iPF2 $\alpha$-III increased amyloid plaque formation and soluble and insoluble $A \beta 1-40$ and $A \beta 1-42$ levels in a TP receptor-dependent manner. TP receptor activation posttranscriptionally stabilized $A P P$ mRNA, providing more APP substrate for $\alpha$ and $\beta$ secretase cleavage, thus increasing $A \beta$ production and amyloid plaque levels. An orally active TP receptor antagonist, S18886, decreased APP levels and significantly lowered amyloid plaques and insoluble $\mathrm{A} \beta$.

Although much of the AD literature has focused on modulating $A \beta$ generation at the level of APP processing, increasing at- 
tention is focusing on the regulation of APP mRNA and protein. For example, familial AD mutations have been identified in the APP promoter region that increase APP mRNA expression and are associated with increased risk for $\mathrm{AD}$ (Theuns et al., 2006), demonstrating that even modest changes in APP expression levels can have profound effects on $\mathrm{AD}$ pathogenesis. Also, APP gene duplications have been identified in families with autosomal dominant early onset AD (Cabrejo et al., 2006). In addition, individuals with Down's syndrome have a triplication of chromosome 21, where the APP gene is located, and as a result, exhibit fourfold to fivefold overexpression of APP (Beyreuther et al., 1993). These individuals develop extracellular plaques 20-30 years earlier than normal individuals (Wisniewski et al., 1985). Additionally, APP mRNA and protein levels have been shown to be elevated in sporadic AD, correlating with elevated $\operatorname{sAPP} \alpha$ and soluble $A \beta$ (Matsui et al., 2007). Certain APP mRNA splice variants have also been shown to be specifically elevated in AD brains (Rockenstein et al., 1995; Preece et al., 2004). These data show that $A \beta$ levels and amyloid plaque load, in both familial and sporadic $\mathrm{AD}$, are extremely sensitive to alterations in APP mRNA and protein levels, and that small changes can accumulate over time to profoundly effect disease.

Currently, the precise mechanism of TP receptor-induced increase in APP mRNA is still unknown. Although the TP receptor is expressed in the brain (Borg et al., 1994; Gao et al., 1997), its function is not well understood. In oligodendrocytes, TP receptors have been shown to mediate cell proliferation, survival, and gene expression (Blackman et al., 1998; Lin et al., 2005). Additional studies have provided evidence of functional TP receptors on hippocampal neurons (Hsu et al., 1996; Nishihara et al., 2000). In non-neuronal systems, the TP receptor has been shown to couple to multiple G-proteins and activates numerous signaling pathways in a cell type-dependent manner, including phopholipase $\mathrm{C}$ activation with $\mathrm{IP}_{3}$ generation and associated increase in calcium (Brass et al., 1987), cAMP generation, (Cracowski et al., 2000; Muja et al., 2001), and activation of the mitogen-activated protein kinase pathway (Gao et al., 2001; Miggin and Kinsella, 2002). Activation of some of these signal transduction pathways has shown similar effects on regulating APP levels. Activation of the prostaglandin $\mathrm{E}_{2}$ receptor induces APP expression at the mRNA and protein level via cAMP (Lee et al., 1999; Pooler et al., 2004). In addition, increases of cAMP by other receptors, such as adrenergic receptors, elevates APP expression (Lee et al., 1997). Also, hepatocyte growth factor receptor stimulation increases APP protein levels via activation of extracellular signal-regulated kinase (ERK) 1/2 (Liu et al., 2003).

$A P P$ mRNA is regulated tightly at the posttranscriptional level. ERK activation has been shown previously to modulate APP mRNA decay (Westmark and Malter, 2001) as does interaction of the $5^{\prime}$ and $3^{\prime}$ untranslated regions of APP mRNA with different RNA binding proteins. For our experiments, however, we are still able to see increases in APP using APP constructs that are deficient in $5^{\prime}$ and $3^{\prime}$ UTRs. TP receptor activation induces a number of downstream signaling pathways that could promote binding of cellular proteins to the coding region of APP mRNA, altering mRNA stability. Multiple RNA binding proteins have been shown in other systems to regulate mRNA stability by binding coding regions (Noubissi et al., 2006; Prechtel et al., 2006; Yarovinsky et al., 2006). In the case of APP, the fragile-X mental retardation protein was recently found to bind to the coding region of APP and promote APP translation (Westmark and Malter, 2007). Additional research is needed to define the precise

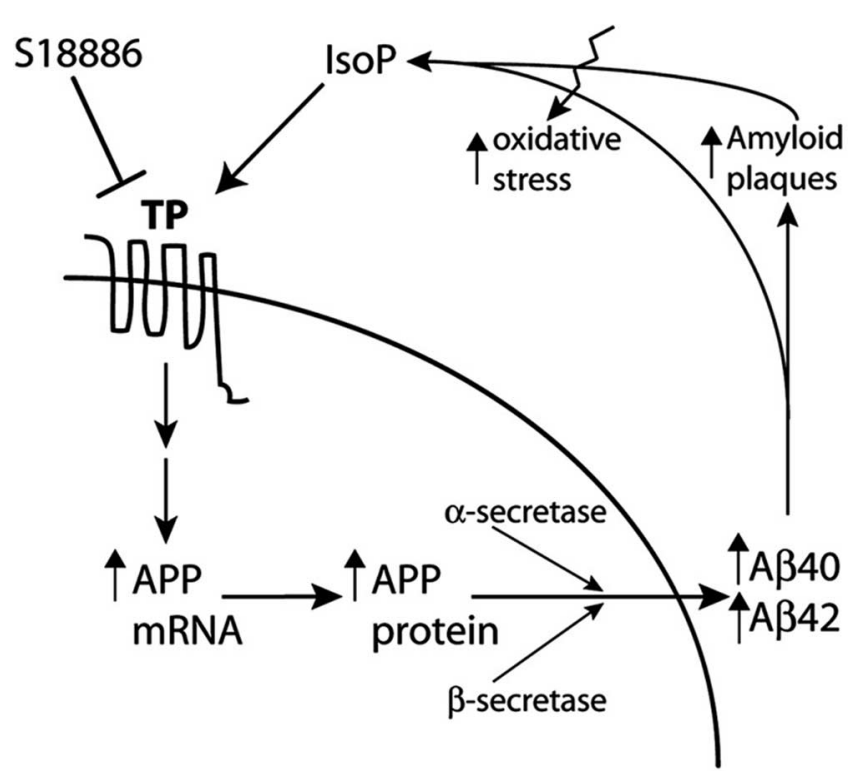

Figure 8. Model depicting mechanism of IsoP-induced increase in $A \beta$ levels. TP receptor activation by IsoP increases APP mRNA, which results in more APP substrate available for proteolytic cleavage and subsequently more $A \beta$ generation. Elevated $A \beta$ levels lead to an increase in amyloid plaque formation in vivo. This model also demonstrates a feedforward mechanism, where early events in amyloid pathology trigger an increase in oxidative stress, elevating isoprostane levels. IsoP can then activate the TP receptor and promote $A \beta$ generation and amyloid pathology. TP receptor antagonist $\mathrm{S} 18886$ blocks activation of this pathway and attenuates formation of amyloid pathology.

target downstream of TP receptor activation that affects APP mRNA stability.

Our data show $\operatorname{sAPP} \alpha$ levels are elevated more dramatically than APP, sAPP $\beta$, or $\mathrm{A} \beta$ species. One possibility for this result is that $\alpha$-cleavage occurs in higher frequencies than $\beta$-cleavage in the cell culture model systems used here. sAPP $\alpha$ accumulates in the media faster and in much greater levels, therefore magnifying the effect shown with TP receptor activation. As shown in Figure $5 D$, sAPP $\alpha$ is increased at $8 \mathrm{~h}$ but not to the same magnitude that we see with overnight I-BOP stimulation, suggesting that accumulation, rather then generation, is responsible for the larger increases in $\mathrm{sAPP} \alpha$ seen with I-BOP stimulation. It is also possible, however, that $\operatorname{sAPP} \alpha$ secretion is independently stimulated by TP receptor activation. Studies have shown that protein kinase C (PKC) activation stimulates sAPP $\alpha$ secretion (Slack et al., 1993; Jolly-Tornetta and Wolf, 2000) and TP receptor activation can activate the PKC pathway (Gao et al., 2001). Therefore, we cannot rule out the possibility that sAPP $\alpha$ levels may be increased to such a dramatic extent because of two mechanisms, increase in APP precursor as well as stimulation of secretion.

Given that isoprostanes are elevated before amyloid plaque formation, it appears that there is a feedforward mechanism where isoprostane and amyloid plaque formation both propagate each other (Fig. 8). Although our studies show that IsoP can increase $\mathrm{A} \beta, \mathrm{A} \beta$ can also induce isoprostane generation (Mark et al., 1999; Pratico et al., 2001) in an age-dependent manner (Brunetti et al., 2004). Our studies also show an increase of IsoP (Fig. $2 B$ ) that is reflective of the increased amyloid load in IsoP-treated mice, further supporting this feedforward model. Increased oxidative insults or decreased antioxidant defenses associated with aging can lead to increased isoprostane levels and promote amyloid plaque formation, generating more oxidative stress and elevating isoprostanes, ultimately leading to $\mathrm{AD}$. 
Our studies highlight a novel pathogenic pathway that promotes $\mathrm{A} \beta$ generation and enhances amyloid plaque formation in a mouse model of AD amyloidosis. This pathway provides a new avenue for $\mathrm{AD}$ drug discovery. Indeed, we found that the orally available TP receptor antagonist S18886 was successful in preventing amyloid plaque formation and decreasing insoluble $\mathrm{A} \beta$ in our AD mouse model. S18886 also decreased APP levels in the mouse brain, providing evidence that the mechanism we observe in cell culture is similar to what occurs in vivo, and again demonstrating that small changes in APP levels can greatly affect AD pathology over time. Although our studies show that TP receptor antagonism attenuates the development of amyloid plaque pathology, it is also important to test whether TP receptor antagonism would be beneficial in reversing amyloid plaque formation in mice further along in the disease process. This study is the first of its kind to suggest the TP receptor signaling pathway as a mediating pathway in $\mathrm{AD}$ pathogenesis. Although existing $\mathrm{TP}$ receptor antagonists have been developed primarily for cardiovascular indications, TP receptor antagonists that readily gain access to the brain may prove beneficial for the treatment of AD.

\section{References}

Audoly LP, Rocca B, Fabre JE, Koller BH, Thomas D, Loeb AL, Coffman TM, FitzGerald GA (2000) Cardiovascular responses to the isoprostanes iPF(2alpha)-III and iPE(2)-III are mediated via the thromboxane A(2) receptor in vivo. Circulation 101:2833-2840.

Banker G, Goslin K, eds (1998) Culturing nerve cells, pp 352-356. Cambridge, MA: MIT.

Beyreuther K, Pollwein P, Multhaup G, Monning U, Konig G, Dyrks T, Schubert W, Masters CL (1993) Regulation and expression of the Alzheimer's beta/A4 amyloid protein precursor in health, disease, and Down's syndrome. Ann NY Acad Sci 695:91-102.

Blackman SC, Dawson G, Antonakis K, Le Breton GC (1998) The identification and characterization of oligodendrocyte thromboxane $\mathrm{A} 2$ receptors. J Biol Chem 273:475-483.

Borg C, Lim CT, Yeomans DC, Dieter JP, Komiotis D, Anderson EG, Le Breton GC (1994) Purification of rat brain, rabbit aorta, and human platelet thromboxane $\mathrm{A} 2 /$ prostaglandin $\mathrm{H} 2$ receptors by immunoaffinity chromatography employing anti-peptide and anti-receptor antibodies. J Biol Chem 269:6109-6116.

Brass LF, Shaller CC, Belmonte EJ (1987) Inositol 1,4,5-triphosphateinduced granule secretion in platelets. Evidence that the activation of phospholipase $\mathrm{C}$ mediated by platelet thromboxane receptors involves a guanine nucleotide binding protein-dependent mechanism distinct from that of thrombin. J Clin Invest 79:1269-1275.

Brunetti L, Michelotto B, Orlando G, Recinella L, Di Nisio C, Ciabattoni G, Vacca M (2004) Aging increases amyloid beta-peptide-induced 8-isoprostaglandin F2alpha release from rat brain. Neurobiol Aging 25:125-129.

Cabrejo L, Guyant-Marechal L, Laquerriere A, Vercelletto M, De la Fournièr F, Thomas-Anterion C, Verny C, Letournel F, Pasquier F, Vital A, Checler F, Frebourg T, Campion D, Hannequin D (2006) Phenotype associated with APP duplication in five families. Brain 129:2966-2976.

Cook DG, Forman MS, Sung JC, Leight S, Kolson DL, Iwatsubo T, Lee VMY, Doms RW (1997) Alzheimer's A beta(1-42) is generated in the endoplasmic reticulum/intermediate compartment of NT2N cells. Nat Med 3:1021-1023.

Cracowski JL, Stanke-Labesque F, Chavanon O, Corompt E, Veitl S, Blin D, Bessard G, Devillier P (2000) Thromboxane A(2) modulates cyclic AMP relaxation and production in human internal mammary artery. Eur J Pharmacol 387:295-302.

de Leon MJ, DeSanti S, Zinkowski R, Mehta PD, Pratico D, Segal S, Rusinek H, Li J, Tsui W, Saint Louis LA, Clark CM, Tarshish C, Li Y, Lair L, Javier E, Rich K, Lesbre P, Mosconi L, Reisberg B, Sadowski M, et al. (2006) Longitudinal CSF and MRI biomarkers improve the diagnosis of mild cognitive impairment. Neurobiol Aging 27:394-401.

Gao H, Peng B, Welch WJ, Wilcox CS (1997) Central thromboxane receptors: mRNA expression and mediation of pressor responses. Am J Physiol Regul Integr Comp Physiol 272:R1493-R1500.
Gao Y, Tang S, Zhou S, Ware JA (2001) The thromboxane A2 receptor activates mitogen-activated protein kinase via protein kinase C-dependent Gi coupling and Src-dependent phosphorylation of the epidermal growth factor receptor. J Pharmacol Exp Ther 296:426-433.

Giasson BI, Ischiropoulos H, Lee VMY, Trojanowski JQ (2002) The relationship between oxidative/nitrative stress and pathological inclusions in Alzheimer's and Parkinson's diseases. Free Radic Biol Med 32:1264-1275.

Gravina SA, Ho L, Eckman CB, Long KE, Otvos Jr L, Younkin LH, Suzuki N, Younkin SG (1995) Amyloid beta protein (A beta) in Alzheimer's disease brain. Biochemical and immunocytochemical analysis with antibodies specific for forms ending at A beta 40 or A beta 42(43). J Biol Chem 270:7013-7016.

Greco A, Minghetti L, Levi G (2000) Isoprostanes, novel markers of oxidative injury, help understanding the pathogenesis of neurodegenerative diseases. Neurochem Res 25:1357-1364.

Grossman M, Farmer J, Leight S, Work M, Moore P, Van Deerlin V, Pratico D, Clark CM, Coslett HB, Chatterjee A, Gee J, Trojanowski JQ, Lee VMY (2005) Cerebrospinal fluid profile in frontotemporal dementia and Alzheimer's disease. Ann Neurol 57:721-729.

Hardy J (2006) A hundred years of Alzheimer's disease research. Neuron 52:3-13.

Hirata M, Hayashi Y, Ushikubi F, Yokota Y, Kageyama R, Nakanishi S, Narumiya S (1991) Cloning and expression of cDNA for a human thromboxane A2 receptor. Nature 349:617-620.

Hsiao K, Chapman P, Nilsen S, Eckman C, Harigaya Y, Younkin S, Yang F, Cole G (1996) Correlative memory deficits, Abeta elevation, and amyloid plaques in transgenic mice. Science 274:99-102.

Hsu KS, Huang CC, Kan WM, Gean PW (1996) TXA2 agonists inhibit highvoltage-activated calcium channels in rat hippocampal CA1 neurons. Am J Physiol 271:C1269-C1277.

Huang JS, Ramamurthy SK, Lin X, Le Breton GC (2004) Cell signalling through thromboxane A2 receptors. Cell Signal 16:521-533.

Ishihara T, Hong M, Zhang B, Nakagawa Y, Lee MK, Trojanowski JQ, Lee VMY (1999) Age-dependent emergence and progression of a tauopathy in transgenic mice overexpressing the shortest human tau isoform. Neuron 24:751-762.

Jolly-Tornetta C, Wolf BA (2000) Regulation of amyloid precursor protein (APP) secretion by protein kinase calpha in human ntera 2 neurons (NT2N). Biochemistry 39:7428-7435.

Kinsella BT, O’Mahony DJ, FitzGerald GA (1997) The human thromboxane $\mathrm{A} 2$ receptor alpha isoform (TP alpha) functionally couples to the $\mathrm{G}$ proteins Gq and G11 in vivo and is activated by the isoprostane 8-epi prostaglandin F2 alpha. J Pharmacol Exp Ther 281:957-964.

Lee EB, Zhang B, Liu K, Greenbaum EA, Doms RW, Trojanowski JQ, Lee VMY (2005) BACE overexpression alters the subcellular processing of APP and inhibits Abeta deposition in vivo. J Cell Biol 168:291-302.

Lee RK, Araki W, Wurtman RJ (1997) Stimulation of amyloid precursor protein synthesis by adrenergic receptors coupled to cAMP formation. Proc Natl Acad Sci USA 94:5422-5426.

Lee RK, Knapp S, Wurtman RJ (1999) Prostaglandin E2 stimulates amyloid precursor protein gene expression: inhibition by immunosuppressants. J Neurosci 19:940-947.

Lin X, Ramamurthy SK, Le Breton GC (2005) Thromboxane A receptormediated cell proliferation, survival and gene expression in oligodendrocytes. J Neurochem 93:257-268.

Ling Y, Morgan K, Kalsheker N (2003) Amyloid precursor protein (APP) and the biology of proteolytic processing: relevance to Alzheimer's disease. Int J Biochem Cell Biol 35:1505-1535.

Liu F, Su Y, Li B, Ni B (2003) Regulation of amyloid precursor protein expression and secretion via activation of ERK1/2 by hepatocyte growth factor in HEK293 cells transfected with APP751. Exp Cell Res 287:387-396.

Mark RJ, Fuson KS, May PC (1999) Characterization of 8-epiprostaglandin F2alpha as a marker of amyloid beta-peptide-induced oxidative damage. J Neurochem 72:1146-1153.

Markesbery WR (1997) Oxidative stress hypothesis in Alzheimer's disease. Free Radic Biol Med 23:134-147.

Matsui T, Ingelsson M, Fukumoto H, Ramasamy K, Kowa H, Frosch MP, Irizarry MC, Hyman BT (2007) Expression of APP pathway mRNAs and proteins in Alzheimer's disease. Brain Res 1161:116-123.

Mattson MP (2004) Pathways towards and away from Alzheimer's disease. Nature 430:631-639. 
Miggin SM, Kinsella BT (2002) Regulation of extracellular signal-regulated kinase cascades by alpha- and beta-isoforms of the human thromboxane A(2) receptor. Mol Pharmacol 61:817-831.

Montine TJ, Markesbery WR, Morrow JD, Roberts LJ (1998) Cerebrospinal fluid F2-isoprostane levels are increased in Alzheimer's disease. Ann Neurol 44:410-413.

Montine TJ, Quinn JF, Montine KS, Kaye JA, Breitner JC (2005) Quantitative in vivo biomarkers of oxidative damage and their application to the diagnosis and management of Alzheimer's disease. J Alzheimers Dis 8:359-367.

Morrow JD, Hill KE, Burk RF, Nammour TM, Badr KF, Roberts LJ (1990) A series of prostaglandin F2-like compounds are produced in vivo in humans by a non-cyclooxygenase, free radical-catalyzed mechanism. Proc Natl Acad Sci USA 87:9383-9387.

Morrow JD, Minton TA, Roberts LJ (1992) The F2-isoprostane, 8-epiprostaglandin F2 alpha, a potent agonist of the vascular thromboxane/ endoperoxide receptor, is a platelet thromboxane/endoperoxide receptor antagonist. Prostaglandins 44:155-163.

Muja N, Blackman SC, Le Breton GC, Devries GH (2001) Identification and functional characterization of thromboxane A2 receptors in Schwann cells. J Neurochem 78:446-456.

Nishihara M, Yokotani K, Inoue S, Osumi Y (2000) U-46619, a selective thromboxane A2 mimetic, inhibits the release of endogenous noradrenaline from the rat hippocampus in vitro. Jpn J Pharmacol 82:226-231.

Noubissi FK, Elcheva I, Bhatia N, Shakoori A, Ougolkov A, Liu J, Minamoto T, Ross J, Fuchs SY, Spiegelman VS (2006) CRD-BP mediates stabilization of betaTrCP1 and c-myc mRNA in response to beta-catenin signalling. Nature 441:898-901.

Pooler AM, Arjona AA, Lee RK, Wurtman RJ (2004) Prostaglandin E2 regulates amyloid precursor protein expression via the EP2 receptor in cultured rat microglia. Neurosci Lett 362:127-130.

Pratico D, Lee VMY, Trojanowski JQ, Rokach J, FitzGerald GA (1998) Increased F2-isoprostanes in Alzheimer's disease: evidence for enhanced lipid peroxidation in vivo. FASEB J 12:1777-1783.

Pratico D, Uryu K, Leight S, Trojanoswki JQ, Lee VMY (2001) Increased lipid peroxidation precedes amyloid plaque formation in an animal model of Alzheimer amyloidosis. J Neurosci 21:4183-4187.

Pratico D, Clark CM, Liun F, Rokach J, Lee VMY, Trojanowski JQ (2002) Increase of brain oxidative stress in mild cognitive impairment: a possible predictor of Alzheimer disease. Arch Neurol 59:972-976.

Prechtel AT, Chemnitz J, Schirmer S, Ehlers C, Langbein-Detsch I, Stulke J, Dabauvalle MC, Kehlenbach RH, Hauber J (2006) Expression of CD83 is regulated by $\mathrm{HuR}$ via a novel cis-active coding region RNA element. J Biol Chem 281:10912-10925.

Preece P, Virley DJ, Costandi M, Coombes R, Moss SJ, Mudge AW, Jazin E, Cairns NJ (2004) Amyloid precursor protein mRNA levels in Alzheimer's disease brain. Brain Res Mol Brain Res 122:1-9.

Rockenstein EM, McConlogue L, Tan H, Power M, Masliah E, Mucke L (1995) Levels and alternative splicing of amyloid beta protein precursor (APP) transcripts in brains of APP transgenic mice and humans with Alzheimer's disease. J Biol Chem 270:28257-28267.
Selkoe DJ (1999) Translating cell biology into therapeutic advances in Alzheimer's disease. Nature 399:A23-A31.

Skovronsky DM, Moore DB, Milla ME, Doms RW, Lee VMY (2000) Protein kinase C-dependent alpha-secretase competes with beta-secretase for cleavage of amyloid-beta precursor protein in the trans-Golgi network. J Biol Chem 275:2568-2575.

Slack BE, Nitsch RM, Livneh E, Kunz Jr GM, Eldar H, Wurtman RJ (1993) Regulation of amyloid precursor protein release by protein kinase $\mathrm{C}$ in Swiss 3T3 fibroblasts. Ann NY Acad Sci 695:128-131.

Tang M, Cyrus T, Yao Y, Vocun L, Pratico D (2005) Involvement of thromboxane receptor in the proatherogenic effect of isoprostane F2alpha-III: evidence from apolipoprotein E- and LDL receptor-deficient mice. Circulation 112:2867-2874.

Theuns J, Brouwers N, Engelborghs S, Sleegers K, Bogaerts V, Corsmit E, De Pooter T, van Duijn CM, De Deyn PP, Van Broeckhoven C (2006) Promoter mutations that increase amyloid precursor-protein expression are associated with Alzheimer disease. Am J Hum Genet 78:936-946.

Trojanowski JQ, Schuck T, Schmidt ML, Lee VMY (1989) Distribution of tau proteins in the normal human central and peripheral nervous system. J Histochem Cytochem 37:209-215.

Tuppo EE, Forman LJ, Spur BW, Chan-Ting RE, Chopra A, Cavalieri TA (2001) Sign of lipid peroxidation as measured in the urine of patients with probable Alzheimer's disease. Brain Res Bull 54:565-568.

Turner RS, Suzuki N, Chyung AS, Younkin SG, Lee VMY (1996) Amyloids beta 40 and beta 42 are generated intracellularly in cultured human neurons and their secretion increases with maturation. J Biol Chem 271:8966-8970.

Vetrivel KS, Thinakaran G (2005) Amyloidogenic processing of betaamyloid precursor protein in intracellular compartments. Neurology 66:S69-S73.

Westmark CJ, Malter JS (2001) Extracellular-regulated kinase controls beta-amyloid precursor protein mRNA decay. Brain Res Mol Brain Res 90:193-201.

Westmark CJ, Malter JS (2007) FMRP mediates mGluR5-dependent translation of amyloid precursor protein. PLoS Biol 5:e52.

Wilson CA, Doms RW, Lee VMY (1999) Intracellular APP processing and A beta production in Alzheimer disease. J Neuropathol Exp Neurol 58:787-794.

Wilson CA, Doms RW, Zheng H, Lee VMY (2002) Presenilins are not required for A beta 42 production in the early secretory pathway. Nat Neurosci 5:849-855.

Wisniewski KE, Wisniewski HM, Wen GY (1985) Occurrence of neuropathological changes and dementia of Alzheimer's disease in Down's syndrome. Ann Neurol 17:278-282.

Yao Y, Zhukareva V, Sung S, Clark CM, Rokach J, Lee VMY, Trojanowski JQ, Pratico D (2003) Enhanced brain levels of 8,12-iso-iPF2alpha-VI differentiate AD from frontotemporal dementia. Neurology 61:475-478.

Yarovinsky TO, Butler NS, Monick MM, Hunninghake GW (2006) Early exposure to IL-4 stabilizes IL-4 mRNA in CD4 + T cells via RNA-binding protein HuR. J Immunol 177:4426-4435. 